\title{
Kualitas Hidup Ibu Hamil pada Masa Pandemic Covid-19
}

Meda Yuliani', Sri Ayu Aryanti²

Program Studi D3 Kebidanan, Fakultas Ilmu Kesehatan, Universitas Bhakti Kencana, Indonesia

1 meda.yuliani@bku.ac.id

²si.ayu@bku.ac.id

\begin{abstract}
ABSTRAK
Ibu hamil merupakan salah satu kelompok rentan, baik dalam kondisi hamil selama pandemic ataupun saat tidak pandemic. sehingga kondisi fisik dan psikologis ibu hamil perlu diketahui. selama pandemic ini ibu hamil dibatasi untuk melakukan pemeriksaan ke instansi kesehatan. Tujuan penelitian untuk mengetahui bagaimana kondisi kualitas hidup ibu hamil selama pandemic dengan mengkaji berdasarkan karakteristik ibu hamil dengan menggunakan instrument kualitas hidup dari WHO yaitu WHOQOL (Quality Of Life ), sehingga kualitas hidup dapat diketahui dari aspek fisik, psikis, social dan lingkungan ibu hamil selama pandemic. Metode dalam penelitian ini menggunakan deskriptif kuantitatif. Menggunakan rancangan penelitian cross sectional, Dengan tahap pengambilan data primer dengan menggunakan kuesioner kualitas hidup dari WHO yang sudah baku yaitu WHOQOL. Sampel dalam penelitian ini adalah seluruh ibu hamil yang datang ke Puskemas Cinunuk, dengan teknik pengambilan sampel menggunakan accidental sampling, dengan jumlah sampel sebanyak 123 ibu hamil. Data hasil penelitian menunjukan bahwa kualitas ibu hamil selama pandemic merasakan dalam kondisi fisik baik ( $62,6 \%$ ) dan kondisi kurang ( 4,9\%), kondisi Psikologis merasa baik (62,6\%) dan kondisi kurang (7,3\%), kondisi sosial merasa baik ( $61,8 \%)$ dan kurang ( $7,3 \%)$, kondisi lingkungan merasa baik ( $72,4 \%)$ dan cukup $(20,3 \%)$. Penilaian kualitas hidup ibu hamil selama pandemic covid-19 ini memberikan gambaran situasi kondisi ibu hamil selama pandemic covid-19, meskipun didpatkan hasil kualitas hidup baik tetapi masih terdapat juga yang kualitas hidup kurang, sehingga diperlukan terus pemantauan kondisi kehamilan selama pandemic covid-19 ini baik dengan self control oleh ibu hamil itu sendiri ataupun self management oleh pihak tenaga Kesehatan
\end{abstract}

Keywords: Ibu hamil, Kualitas hidup, Pandemic Covid-19

\section{PENDAHULUAN}

Kehamilan digambarkan sebagai fertilisasi

atau penyatuan sperma dan ovum dan terus berlanjut dan berimplantasi. Kehamilan yang khas terjadi dalam 280 hari dari saat pembuahan sampai bayi lahir. ( 40 minggu atau 9 bulan 7 hari) (Irianti et al., 2015). Kehamilan adalah proses fisiologis dan alami. Fase embrio merupakan manifestasi dari rasa realisasi diri dan identitas yang diinginkan sebagian besar wanita. Sang ibu tidak menyadari bahwa dia hamil pada awalnya. Padahal, tubuhnya aktif dalam menyesuaikan diri dengan kehamilan. Melalui penyesuaian ini, pergeseran fisiologis dan psikologis mungkin terjadi. Kehamilan adalah salah satu peristiwa yang paling meresahkan dalam kehidupan seorang wanita juga. Perempuan harus melakukan perubahan karena dapat berdampak besar pada kesehatan fisik dan kondisi psikologis mereka. (Bidan dan Dosen Kebidanan Indonesia, 2017).

Awalnya sumber kegembiraan, kondisi hamil bisa menjadi kekhawatiran khusus yang dihasilkan oleh kehamilan berisiko tinggi. Data Kementerian Kesehatan (Kemenkes) Indonesia tahun 2015 mengungkapkan bahwa 305 dari 100.000 kelahiran hidup di Indonesia berakhir dengan kematian ibu.

Secara fisik dan mental, masalah kesehatan ibu hamil mempengaruhi kualitas hidup ibu. Wanita dengan kondisi abnormal yang dapat meningkatkan risiko kehamilan, memperkirakan $5-10 \%$ berisiko tinggi selama kehamilan (Akhyar, 2010).

Ibu hamil merupakan salah satu kelompok rentan, baik dalam kondisi hamil selama pandemic ataupun saat tidak pandemic. sehingga kondisi fisik dan psikologis ibu hamil perlu diketahui. selama 
pandemic ini ibu hamil dibatasi untuk melakukan pemeriksaan ke instansi kesehatan. Tetapi meskipun demikian asuhan Antenatal care tetap harus diberikan. Dampak pandemic pada kehamilan dalam jangka pendek yaitu risiko komplikasi yang bisa saja terjadi saat kehamilan muda, dimana ibu hamil seperti yang diketahui kebijakan untuk melakukan kunjungan pemeriksaan dibatasi, banyak petugas medis yang focus terhadap penanganan covid-19 (Adhiyasasti, 2020).

Wanita dengan kehamilan berisiko tinggi harus mempersiapkan diri untuk menghadapi kehamilannya dengan lebih memperhatikan kesehatannya. 90-95 persen ibu hamil, bahkan dalam kehamilan berisiko, dapat melahirkan dengan selamat dan memiliki bayi yang sehat dengan memperbaiki masalah kesehatan yang secara langsung mempengaruhi peningkatan kualitas hidup. Jika tanda-tandanya diidentifikasi sedini mungkin, kehamilan berisiko tinggi dapat dicegah dan dikelola dengan tepat untuk mengambil langkah-langkah. Kualitas hidup adalah keseimbangan antara peluang atau kendala hidup yang dihasilkan dari interaksi individu-lingkungan (Renwick \& Brown, 1996).

\section{METODE}

Penelitian ini didasarkan pada metode penelitian kuantitatif. Alat kualitas hidup WHOQOL-BREF digunakan untuk mengumpulkan data studi, serta hasil data yang didapat dan digunakan dalam analisis merupakan data yang berupa angka atau data statistic. Instrument kualitas hidup yang dipergunakan sebelumnya sudah pernah dipakai dan dilakukan pengujian secara validitas, serta instumen ini sudah baku digunakan untuk mengukur kuliatas hidup. Seluruh ibu hamil akan dilakukan pengkajian melalui penyebaran kuesioner ini dengan proses wawancara, kualitas hidup pada ibu hamil akan dikaji berdasarkan karakteristik dari ibu hamil tersebut. Penelitian yang pernah dilakukan di Indonesia sebelumnya mengkaji pada ibu hamil dengan risiko dan menggunakan instrument WHOQOL, pada penelitian ini sasarannya dilakukan pada seluruh ibu hamil dengan menggunakan instrument kualitas hidup tersebut.

Sampel dalam penelitian ini menggunakan teknik accidental sampling, yaitu tergantung pada saat reponden datang ke puskesmas, tetapi karena keterbatasan saat pandemic seperti ini maka waktu penyelesaian akan disesuikan sampai tercukupinya sampel minimal, sampel yang diperoleh sebanyak 123 responden. variabel dalam penelitian ini yaitu kualitas hidup yang yang dilihat dari berbagia indicator, fisik, social, lingkungan. Yang nantinya indicator kualitas hidup tersebut dikaitkan dengan kondisi kehamilan selama pandemic.

Alat ukur kualitas hidup WHOQOL-BRE memberikan gambaran kualitas hidup individu yang dapat dilihat secara spesifik melalui empat domain, item pertama mengenai persepsi individu terhadap kualitas hidup secara keseluruhan dan item kedua mengenai persepsi kualitas hidup individu pada setiap dimensi. Skor dimensi merupakan skala positif dimana semakin tinggi skor menandakan semakin tinggi kualitas hidup individu (World Health Organization, 2012). Responden diminta untuk menilai intensitas, kapasitas, frekuensi dan evaluasi dengan skala Likert pada setiap itemnya. Responden menilai setiap item dari skala 1 sampai 5 berdasarkan penghayatan responden mengenai tujuan, harapan standar dan hal lainnya yang 
menjadi perhatian individu selama empat minggu terakhir.

Skor pada setiap domain yang berasal dari alat ukur (raw score) WHOQOL-BREF harus dikonversi untuk membandingkan nilai skor alat ukur ini dengan nilai skor yang digunakan dalam pengukuran WHOQOL - 100 (World Health Organization, 2012). Skor tiap domain (raw score) ditansformasikan dalam skala 0 - 100, untuk transformasi skor sudah baku (Balela, 2015).

Setelah data diberikan dari subjek, itu akan dilanjutkan melalui banyak fase untuk mengevaluasi data dan mengembangkan kesimpulan yang menanggapi topik studi. Siswa kemudian dapat memeriksa data. Statistik tersebut termasuk dalam statistik deskriptif berdasarkan pengolahan datanya. Statistik deskriptif adalah statistik tentang bagaimana data dideskripsikan agar mudah dipahami (Siregar, 2011). Adapun langkah-langkah pengolahan dan analisis data tersebut adalah sebagai berikut : Menghitung Presentase Data, Karakteristik ibu hamil, Mengetahui nilai dari tiap variable/ domain pada instrument WHOQOL, Mencari rata-rata dari setiap variable data

\section{HASIL DAN PEMBAHASAN}

Distribusi frekuensi karakteristik ibu hamil

\begin{tabular}{lcc}
\hline Usia & $\mathrm{F}$ & $\%$ \\
$<20$ tahun & 10 & 8.1 \\
21-35 tahun & 95 & 77.2 \\
$>35$ Tahun & 18 & 14.6 \\
\hline & & \\
\hline Pendidikan & & \\
SD & 3 & 2.4 \\
SMP & 21 & 17.1 \\
SMA/SMK & 71 & 57.7 \\
D3/D4 & 9 & 7.3 \\
S-1 & 17 & 13.8 \\
S-2 & 2 & 1.6 \\
\hline
\end{tabular}

\begin{tabular}{|c|c|c|}
\hline \multicolumn{3}{|l|}{ Pekerjaan } \\
\hline IRT & 78 & 63.4 \\
\hline SWASTA & 28 & 22.8 \\
\hline GURU & 8 & 6.5 \\
\hline BURUH & 5 & 4.1 \\
\hline PNS & 2 & 1.6 \\
\hline PERAWAT & 2 & 1.6 \\
\hline \multicolumn{3}{|l|}{ Jumlah } \\
\hline $\begin{array}{l}\text { GRAVIDA } \\
\text { KE } 1\end{array}$ & 53 & 43.1 \\
\hline $\begin{array}{l}\text { GRAVIDA } \\
\text { KE } 2\end{array}$ & 40 & 32.5 \\
\hline $\begin{array}{l}\text { GRAVIDA } \\
\text { KE } 3\end{array}$ & 18 & 14.6 \\
\hline $\begin{array}{l}\text { GRAVIDA } \\
\text { KE } 4\end{array}$ & 9 & 7.3 \\
\hline $\begin{array}{l}\text { GRAVIDA } \\
\text { KE } 5\end{array}$ & 2 & 1.6 \\
\hline $\begin{array}{l}\text { GRAVIDA } \\
\text { KE } 6\end{array}$ & 1 & 0.8 \\
\hline \multicolumn{3}{|l|}{ Usia } \\
\hline Kehamilan & & \\
\hline Trimester 1 & 21 & 17.07 \\
\hline Trimester 2 & 45 & 36.59 \\
\hline Trimester 3 & 57 & 46.34 \\
\hline Total & 123 & 100.0 \\
\hline
\end{tabular}

menyebabkan perubahan fisiologis dan psikologis pada tubuh wanita. Oleh karena itu, adaptasi tertentu terhadap perubahan ini diperlukan. (Wahyuni, 2020).

Bukti umum dari temuan menunjukkan bahwa sebagian besar wanita yang hamil berusia antara 21-35 tahun dan usia reproduksi mereka optimal pada usia tersebut. Tetapi dari data tersebut masih ada usia beresiko yaitu usia diatas 35 tahun dan usia dibawah 20 tahun, yang mana pada usia tersebut merupakan usia resiko pada proses kehamilan ataupun persalinan. Sehingga pemeriksaan kehamilan pada ibu dengan faktor resiko perlu dilakukan rutin sebagai bentuk deteksi dini penylit yang terjadi pada kehamilan, tetapi bukan hanya pada ibu hamil dengan usia faktor 
resiko saja, tetapi semua ibu hamil dianggap beresiko karena ibu hamil merupan kelompok rentan termasuk juga terhadap penyakit covid -19 saat ini. Selain usia data umum lain yang diperoleh adalah jumlah kehamilan. Didapatkan data bahwa lebih dari setengahnya merupakan kehamilan pertama dan juga Sebagian kecil repsonden merupakan kehamilan grandemulti atau kehamilan lebih dari 4, Kedua kategori inipun dianggap merupakan faktor resiko sehingga perlu pemberian informasi mengenai tanda bahaya pada kehamilan selama kehamilan.

Kehamilan berisiko tinggi memiliki peluang kematian yang lebih tinggi sebelum dan sesudah kelahiran (baik untuk ibu dan bayi), penyakit dan cacat bahkan kematian. Kehamilan risiko tinggi pada ibu hamil meliputi usia (terlalu muda, di bawah usia 20 tahun, di bawah usia 35 tahun); jarak kurang dari 2 tahun.; tinggi lebih kecil dari $145 \mathrm{~cm}$, lingkar lengan atas kurang dari $23,5 \mathrm{~cm}$; hemoglobin kurang dari $11 \mathrm{~g} / \mathrm{dl}$; kehamilan lebih dari 4 kali(Azwar, 2008).

Tabel 2. distribusi frekuensi kualitas hidup ibu hamil selama masa pandemic Covid-19

\begin{tabular}{ccccccccccc}
\hline & $\begin{array}{c}\text { Sangat } \\
\text { baik }\end{array}$ & Baik & Cukup & $\begin{array}{c}\text { Kuran } \\
\mathrm{g}\end{array}$ \\
\hline $\begin{array}{c}\text { Domain } \\
\text { kualitas } \\
\text { Hidup }\end{array}$ & $\mathrm{F}$ & $\%$ & $\mathrm{~F}$ & $\%$ & $\mathrm{~F}$ & $\%$ & $\mathrm{~F}$ & $\%$ & $\mathrm{~F}$ \\
\hline Fisik & 5 & 4.1 & 7 & 62. & 3 & 28. & 6 & 4. & 12 \\
& & & 7 & 6 & 5 & 5 & & 9 & 3 \\
Psikolo & 9 & 7.3 & 7 & 62. & 2 & 22. & 9 & 7. & 12 \\
$\quad$ gis & & & 7 & 6 & 8 & 8 & & 3 & 3 \\
& & & & & & & & & \\
Sosial & 13 & 10. & 7 & 61. & 3 & 27. & 9 & 7. & 12 \\
& & 6 & 6 & 8 & 4 & 6 & & 3 & 3 \\
lingkung & 9 & 7.3 & 8 & 72. & 2 & 20. & 0 & 0 & 12 \\
$\quad$ an & & & 9 & 4 & 5 & 3 & & & 3 \\
\hline
\end{tabular}

WHO mengatakan bahwa kualitas hidup adalah rasa tempat individu dalam masyarakat 3 dalam konteks nilai-nilai dan budaya lokal dan terhubung dengan keinginan dan harapan, yang tidak hanya fisik tetapi juga mental. (Listyawati, 2017).

Kehamilan adalah suatu keadaan tertentu yang bukan merupakan penyakit maupun keadaan kesehatan yang normal. Perhatian telah dikhususkan untuk hubungan antara normal, proses fisiologis kehamilan dan kualitas hidup wanita pada periode kehamilan ini kurang diperhatikan. Kualitas umum dan kualitas khusus kehidupan wanita hamil bervariasi. Kuesioner spesifik sederhana, yang juga berlaku dalam perawatan prenatal, dirancang dan divalidasi untuk pengukuran kualitas hidup terutama untuk kondisi Wanita hamil. ( Vachkova., 2013). Secara fisik dan mental, masalah kesehatan pada ibu hamil mempengaruhi kualitas hidup ibu. Wanita berisiko selama kehamilan terutama mereka yang mempunyai kondisi abnormal. Sehingga pada penelitian ini bertjuan untuk mengetahui kondisi ibu hamil hamil selam pandemic covid-19 ini, dengan menggunakan kuesioner kualitas hidup. Kuesioner kualitas hidup ini secara umum dapat digunakan untuk mendeskripsikan kondisi ibu hamil, dari asfek Totijsik, psikologis, social dan lingkungan.

$\%$ Dari hasil yang diperoleh kualitas hidup ibu hamil selama pandemic covid -19 ini untuk domain kpodisi fisik lebih dari setengah responden dalam kondisi baik ( $62,6 \%$ ) dan Sebagian kecil rësponden dalam kondisi kurang ( $4,9 \%)$. Walaupun kondisi persepsi kualitas fisik baik, tetapi peffu terus ditingkatkan kewaspadaan dalam self management kepada responden, karena ibu hamil Selain itu kondisi fisiologis selama kehamilanpun terdapat perubahan yang dapat berdampak pada fisik. Kemudian yang perlu diperhatikan juga hasil 
penelitian didapatkan juga ibu hamil selama pandemic covid-19 ini kondisi fisiknya dalam kategori kurang, dan hasil pengkajian didapatkan bahwa ibu yang mengalami kondisi fisik kurang yaitu pada ibu berusia diatas 35 tahun, ibu yang bekerja sebagai buruh dan pada ibu rumah tangga (IRT). Begitupun hasil penelitian didapatkan , skor kualitas hidup terendah diperoleh pada keterbatasan fungsional fisik, masalah kesehatan dan Vitalitas pada ibu hamil. Hal itu pada pengukuran kualitas hidup menggunakan SF-36 berkorelasi dengan usia, usia kehamilan, jumlah kehamilan, pendidikan dan pendapatan. Faktor negatif yang dapat mempengaruhi kualitas hidup selama kehamilan perlu dilakukan perencanaan untuk mengurangi dampaknya sehingga dapat meningkatkan kualitas hidup diantar Wanita hamil. (Fatemeh., 2010). Wanita hamil yang dites positif COVID-19, ada beban yang lebih besar secara signifikan pada kesehatan fisik wanita tersebut. Tetapi tidak ada perbedaan yang signifikan antara ksehatan mental dan kesejahteraan. Kesehatan mental dan status psikologis serupa pada kedua kelompok ( covid dan non-Covid). Pelayanan yang berkualitas tinggi selama pandemi dimungkinkan untuk diberikan dalam pengaturan bersalin, terlepas dari status COVID pasien. (Fatimah,.,2020).

Walaupun kondisi pandemic covid-19 ini membatasi semua aspek termasuk pelayanan asuhan kehamilan, tetapi saat ibu hamil perlu diingatkan untuk tetap melakukan kunungan setiap ada keluhan, dan mengoptimalkan asuhan pada saat kunjungan dengan tetap memperhatikan protokol kesehatan. Asuhan antenatal memberikan manfaat yaitu dengan menemukan berbagai kelainan yang menyertai hamil dini, sehingga dapat diperhitungkan dan dipersiapkan langkah-langkah dalam penolong persalinannya. (Maryam., 2017).

Kehamilan adalah perjalanan hidup itu sendiri, sementara pandemi menyebar ke seluruh dunia. Kehamilan pada wanita dapat mempengaruhi kesehatan ibu dan janin.

Dari hasil yang diperoleh kualitas hidup ibu hamil selama pandemic covid -19 ini untuk domain kondisi psikologis lebih dari setengah responden dalam kondisi baik ( 62,6 \%) dan Sebagian kecil responden dalam kondisi kurang ( 7,3 \%). Pandemi covid-19 sebagai salah satu pengaruh kecemasan ibu dalam menghadapi persalinan. Menurut American College of Obstetricians and Gynecologists, penelitian sebelumnya menunjukkan bahwa ibu hamil berisiko lebih tinggi terkena virus Covid-19 karena perubahan imunologis dalam kehamilan, yang dapat meningkatkan risiko infeksi dan kematian bagi ibu hamil. (Zulfiana et al., 2021). Dengan pengalaman kondisi klinis dari coronavirus sebelumnya terinfeksi, tindakan kesehatan masyarakat dan ketakutan terhadap infeksi covid-19 memiliki efek psikologis negatif pada kondisi Wanita hamil. Studi ini menunjukkan bahwa wabah COVID-19 mempengaruhi kesehatan mental ibu hamil secara negative yang mengarah pada hasil kelahiran yang merugikan. (Reyhan ayaz., 2020)

Dari hasil yang diperoleh kualitas hidup ibu hamil selama pandemic covid -19 ini untuk domain kondisi Sosial lebih dari setengah responden dalam kondisi baik ( $62,6 \%$ ) dan Sebagian kecil responden dalam kondisi kurang ( 7,3\%).

Hubungan sosial terdiri dari kontak manusia, bantuan sosial dan kegiatan sosial. Ikatan individu 
dengan orang lain adalah hubungan pribadi. Dukungan sosial mendefinisikan bantuan yang diterima orang-orang dari lingkungan sekitar.(Jacob \& Sandjaya, 2018).

Faktor sosial pada ibu hamil dalam kategori baik, disini ibu hamil merasakan mendapat dukungan dari keluarga, baik suami ataupun anggota keluarga lain, serta disini ibu hamil tidak ada kendala melakukan aktivitas sosialnya. Responden yang merasa kurang terhadap faktor sosial Sebagian kecil dikarenakan ibu hamil dengan kondisi yang jauh dengan suami, sehingga merasa dukungan dari suami dirasa kurang,.

Dari hasil yang diperoleh kualitas hidup ibu hamil selama pandemic covid -19 ini untuk domain kondisi lingkungan lebih dari setengah responden dalam kondisi baik ( $72,4 \%$ ) dan Sebagian kecil responden dalam kondisi kurang ( $20,3 \%$ ). Kondisi ibu hamil yang secara usia sudah dewasa, sehingga mendorong untuk terbentuknya pola adaptasi terhadap lingkungan, selain itu juga lingkungan tempat tinggal dapat memenuhi kebutuhan, walaupun ada sebagain kecil yang merasakn informasi yang didpatkan belum mencukupi terutama tentang penyakit covid-19 ini. Sehingga ibu hamil selama pandemic covid-19 ini dapat merasakan kondisi lingkungan baik dan cukup. Kehamilan adalah waktu kapan wanita sebaiknya untuk lebih peduli terhadap kesehatannya sendiri dan juga mendapat perhatian yang lebih besar dari tenaga kesehatan, dalam hal ini terutama bidan. Meskipun hasil pemeriksaan normal, tetapi pelayanan pada ibu hamil tersebut sebagai sarana untuk menyaring atau mendeteksi kualitas hidup wanita hamil. Mengevaluasi kualitas dari kehidupan adalah penting di dalam ketentuan dini pencegahan pengukuran selama kehamilan. Sebagai tenaga kesehatan perlu meningkatankan kesejahteraan ibu hamil melalui pelayanan antenatal untuk meningkatkan kualitas hidup Wanita hamil tersebut. (Mazuchova., 2018)

\section{KESIMPULAN}

Wabah COVID-19 mengancam seluruh penduduk. Populasi tertentu seperti wanita hamil diperkirakan memiliki risiko lebih tinggi dan lebih mungkin terkena penyakit menular.. Selama kehamilan terdapat perubahan baik secara fisiologis dan psikologis, pandemic covid-19 ini memberikan dampak tidak hanya bagi kesehatan fisik tetapi juga perubahan pada psikologis, yang juga dapat menyebabkan perubahan kualitas hidup pada orang tersebut termasuk ibu hamil selama pandemic covid-19. Kualitas hidup ipada 123 ibu hamil selama pandemic covid-19 ini menunjukan Sebagian besar dalam kondisi baik, tetapi masih terdapat ibu hamil dengan kondisi kurang yang termasuk didalamnya adalah ibu hamil dengan usia diatas 35 tahun, kualitas hidup pada domain psikologis didapatkan hasil Sebagian besar dalam kondisi baik,tetapi mereka merasa mempunyai kekhawtiran dengan kehamilan selama pandemic covid-19 ini, kemudian juga terdapat ibu hamil dengan kondisi kurang untuk domain psikologisnya, untuk kuliatas hidup pada doamian social dan lingkungan Sebagian besar pada kondisi baik dan cukup. Penilaian kualitas hidup ibu hamil selama pandemic covid-19 ini memberikan gambaran situasi kondisi ibu hamil selama pandemic covid-19, meskipun didpatkan hasil kualitas hidup baik tetapi masih terdapat juga yang kualitas hidup kurang, sehingga diperlukan terus pemantauan kondisi kehamilan selama 
pandemic covid-19 ini baik dengan self control oleh ibu hamil itu sendiri ataupun self management oleh pihak tenaga kesehatan.

\section{DAFTAR PUSTAKA}

Adhiyasasti, M. 2020. Dampak Kehamilan Saat Pandemi, dari Komplikasi Hingga Ekonomi. www.skata.info/article/detail/698/dampakkehamilan-saat-pandemi-dari-komplikasihingga-ekonomi

Akhyar, Y. 2010. Deteksi Ibu Hamil Resiko Tinggi (Bumil Risti) di Posyandu. www.yayanakhyar.wordpress.com/2010 /05/11/ deteksi-ibuhamil-resikotinggi-bumilristi-di-posyandu/

Balela, S.A. 2015. Hubungan antara kualitas hidup dengan harga diri lansia yanng tinggal di rumah di RW.8 Bratang Binangun Surabaya Kelurahan Barata Jaya Kecamatan Gubeng Surabaya. Universitas Katolik Widyamandala.

Bidan dan Dosen Kebidanan Indonesia. 2017. Kebidanan Teori dan Asuhan Volume 2. EGC Medical Publisher.

Fatemeh A, Azam B, Nahid M. Quality of life in pregnant women results of a study from Kashan, Iran. Pak J Med Sci 2010;26(3):692697

Fátimah Alaya, Amy P Worrall, Fiona O'Toole, et al. Health-related Quality of Life and Quality of Care in pregnant and postnatal women during the COVID-19 pandemic: a case control study. Authorea. September 28, 2020.

DOI:

10.22541/au.160133482.28247071

Vachkova et al.: The evaluation of the psychometric properties of a specific quality of life questionnaire for physiological pregnancy. Health and Quality of Life Outcomes 2013 11:214 doi:10.1186/14777525-11-214.

Irianti, B., Halida, E.M., Duhita, F., Prabandari, F., Yulita, N., Yulianti, N., Hartiningtiyaswati, S., Anggraini, Y. 2015. Asuhan kehamilan berbasis bukti: paradigma baru dalam asuhan kebidanan. Sagung Seto.

Jacob, D., Sandjaya, S. 2018. Faktor - Faktor yang Mempengaruhi Kualitas Hidup Masyarakat Karubaga District Sub District Tolikara Provinsi Papua. Jurnal Nasional IImu Kesehatan, 1(1), 1-16.

Listyawati, E.F. 2017. Kualitas Hidup Pada Ibu
Dengan Kehamilan Risiko Tinggi. www.osf.io/preprints/inarxiv/492ea/

Maryam, Khoirotun Chisan and Siti, Tyastuti and Nur, Djanah (2018) . Tesis Karakteristik Ibu Hamil Di Puskesmas Karangmojo I Kabupaten Gunungkidul tahun 2017

Mazúchová L, Kelčíková S, Dubovická Z. Measuring women's quality of life during pregnancy: Measuring women's quality of life during pregnancy. Kontakt 2018; 20(1): e31-e36; http://dx.doi.org/10.1016/j.kontakt.2017.11.00 4

Renwick, R., Brown, I. 1996. Quality of Life, Health Promotion \& Rehabilitation. Sage Publication, Inc.

Reyhan Ayaz. Anxiety and depression symptoms in the same pregnant women before and during the COVID-19 pandemic Journal of Perinatal Medicine, 000010151520200380, elSSN 1619-3997, ISSN 0300-5577, DOI: https://doi.org/10.1515/jpm-2020-0380.

Siregar, S. 2011. Statistik Deskriptif untuk Penelitian. Raja Grafindo Persada.

Wahyuni, N.C. 2020. Indonesia Currently Has Highest Covid-19 Mortality Rate in Asia. Jakarta Globe. jakartaglobe.id/news/indonesia-currently-hashighest-covid19-mortality-rate-in-asia

World Health Organization. 2012. WHO Quality of Life-BREF www.who.int/substance (WHOQOL-BREF). abuse/research tools/whoqolbref/en/

Zulfiana, E., Cikmah, A., Latifah, U. 2021. Peningkatan Pengetahuan tentang Kesiapan Mental pada Ibu Hamil Menghadapi Persalinan saat Pandemi Covid-19 di Posyandu. JPM: Jurnal Pengabdian Masyarakat, 1(3), 75-77. 

